ÉGYPTE monde arabe

\section{Égypte/Monde arabe}

$11 \mid 2014$

Ville et révolution en Égypte

\title{
Informal Areas: Shortcomings and New Perspectives in Post-graduate Programmes
}

\author{
Heba Safey Eldeen
}

\section{(2) OpenEdition \\ 12 Journals}

Electronic version

URL: https://journals.openedition.org/ema/3353

DOI: $10.4000 /$ ema.3353

ISSN: 2090-7273

Publisher

CEDEJ - Centre d'études et de documentation économiques juridiques et sociales

\section{Printed version}

Date of publication: 6 April 2014

Number of pages: 283-315

ISBN: 978-2-905838-84-1

ISSN: 1110-5097

Electronic reference

Heba Safey Eldeen, "Informal Areas: Shortcomings and New Perspectives in Post-graduate Programmes", Égypte/Monde arabe [Online], 11 | 2014, Online since 09 April 2014, connection on 07 July 2022. URL: http://journals.openedition.org/ema/3353 ; DOI: https://doi.org/10.4000/ema.3353 


\section{INFORMAL AREAS: SHORTCOMINGS AND \\ NEW PERSPECTIVES IN POST-GRADUATE PROGRAMMES}

RÉSUMÉ

Partant de l'argument que les récents projets de développement urbain du Caire ont eu lieu au détriment des plus pauvres, cet article vise à reconsidérer les pratiques de l'urbanisme dans les zones informelles en Egypte. Jusqu'à présent, les solutions mises en avant par le gouvernement ont été dominées par une logique d'intervention physique : mise à niveau et intégration des zones informelles aux quartiers officiels, limitation de leur extension, ou éradication. Ces approches ignorent la dimension sociale des quartiers informels. De plus, ni le gouvernement ni le secteur privé ne se sont montrés capables de fournir un nombre suffisant de logements abordables pour la majorité des citadins. Cet article soutient que l'une des causes de l'inadaptation des politiques visant les quartiers informels réside dans la manière dont ils sont abordés dans les cursus d'architecture en Egypte. Les cours portant sur les zones informelles insistent sur l'écart entre les anticipations du concepteur et l'utilisation réelle, selon une attitude déterministe de I'architecte qui est une longue tradition dans la profession. L'article propose également quelques suggestions pour des cours qui prendraient en compte ces lacunes.

MOTS CLÉS :

Formations $d^{\prime}$ 'urbanisme et $d^{\prime}$ architecture, zones informelles, psychologie environnementale. 
ABSTRACT

Based on the argument that Cairo's recent urban development projects took place at the expense of the urban poor, this article aims to reconsider the processes of urban practices towards informal areas in Egypt. Until now, solutions put forth by the government have been informed by physically-oriented thinking: upgrading and merging informal areas within formal city districts, buffering them, or eradicating them. In this regard, these are approaches that ignore the social aspects of informal neighbourhoods. Moreover, there has been a long-term inability of the government and the private sector to provide enough affordable accommodation for a majority of urban dwellers. This article argues that one of the reasons for the discrepancies in informal neighbourhood policy originates in the way they are tackled in local architecture school curricula. Courses dedicated to informal areas focus on the gap between the designer's anticipations and actual use; this is partly due to the designer's deterministic attitude shaped by a long tradition in the profession. The article also offers some specific suggestions for new courses that could help with these shortcomings.

KEYWORDS:

Urban Education, Informal Areas, Postgraduate Urban Programs, Undergraduate Urban Programs, Environment-Behavior Studies. 


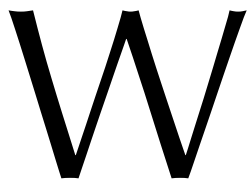

ith the massive changes taking place in Egypt over the past three years, it was hoped that urban practices would reconsider the marginalised urban poor who were long excluded from developmental plans. The former regime launched several associations, organisations, and funds, and dedicated some efforts to solving the problem. However, these solutions were limited to physical-oriented approaches that had little to do with the roots of the problem. These incompetent policies for informal areas were inherited from the former regime and were continued under the Muslim Brotherhood rule. A quick look on the informal areas' map reveals the regrettable truth: severe urban deterioration and an increased "informalisation" in all qualities all over the country. In the 2012 elections, all presidential platforms were loaded with promises of developing and upgrading informal areas. New terms are often cited, such as urban democracy, urban governance, and many others, but are not by any means practiced. Indeed, the statistics and reasons for the cause of informal areas fall beyond the scope of this article. Yet, urbanism is ever-intertwined with politics, and the urban dimensions of Egypt are currently changing with the political transitions. From here, some questions are raised: Are we as educators and educational institutions actually involved in any local problems? Are we preparing our future designers/decision makers to contribute to our local agendas? Now, in one of the most vibrant moments of Egypt's contemporary history, dealing with informal areas in Egypt should be our top priority. Despite this, definitions, typologies, conditions, and numerical figures vary from one organisation to the other! ${ }^{1}$ On several occasions, the World Bank Group described informal settlements,

1. "Informality is the citizen's holding of land and building on it privately whereby violating the regulations for sound planning such as the building code."(El-Diwany, Sherif and Mohamed Kamel, Quoted in Ibrahim, Mohamed: Towards Reliable Spatial Database of Informal Areas in Greater Cairo Region: Identifying Informal Areas in Greater Cairo Region. International Workshop on Spatial Information for Sustainable Management of Urban Areas. FIG Commission 3 - Workshop 2009. Mainz, Germany.

- "Informal areas are unplanned spontaneous high density expansions around existing cities or villages." (Housing Committee of the Peoples' Assembly).

- "Informal Settlements are "traps of poverty and deprivation" or "misery belts". (National Council for Social Services and Development) Quoted in Ibrahim, Mohamed: Towards Reliable Spatial Database of Informal Areas in Greater Cairo Region: Identifying Informal Areas in Greater Cairo Region. International Workshop on Spatial Information for Sustainable Management of Urban Areas. FIG Commission 3 - Workshop 2009. Mainz, Germany. 
slums, and squatter settlements as they share the same miserable living conditions, as follows: ${ }^{2}$ Lack of basic physical infrastructures networks such as potable water, wastewater, solid waste system, electricity, roads and emergency access; lack of basic community services such as educational, health, and social facilities; social segregation between slums and more upscale neighbourhoods; the unplanned development of settlements increases the complication in the provision of services.

The UN-Habitat (2002) has its own definition of informal areas: Informal Areas are characterised by a lack of access to improved water and sanitation facilities; insufficient living area; overpopulation; inadequate structural quality/durability of dwellings; and no security of tenure. In addition, the General Organization for Physical Planning (GOPP) has its own definition: Informal areas are all areas that have been developed by individual efforts, whether single or multi-story buildings or shacks, in the absence of law and layout planning. They have been developed on lands that are not assigned in the city's master plan for building. The buildings' structural conditions might be good; however, they might be environmentally or socially unsafe and lack basic services and utilities.

After the Manshiet Nasser rockslide in 2008, a new definition was announced in the building bylaw n 119 for the year 2008: "Unplanned areas: areas that have been developed without applying detailed plans, land division plans for planning and building regulations". The law has also classified informal areas into two main categories:

1. Unplanned areas are mainly acceptable concrete structures built on privately owned agricultural land which becomes consolidated over time and fed with infrastructures and services.

2. Areas of re-development: Areas where the uses are not suitable for their prime location and usually dealt with through partial or complete redevelopment.

This second category includes legal deteriorated inner-city slums, squatter shantytowns and also parts of cemeteries used for living purposes. The ISDF (Informal Settlements Development Fund) has classified informal settlements into: legal and illegal areas, categorised into acceptable physical structures (unplanned) and deteriorated physical structures (old quarters, legal villages, shanty towns, and unsafe areas).

2. World Bank, 2008. 


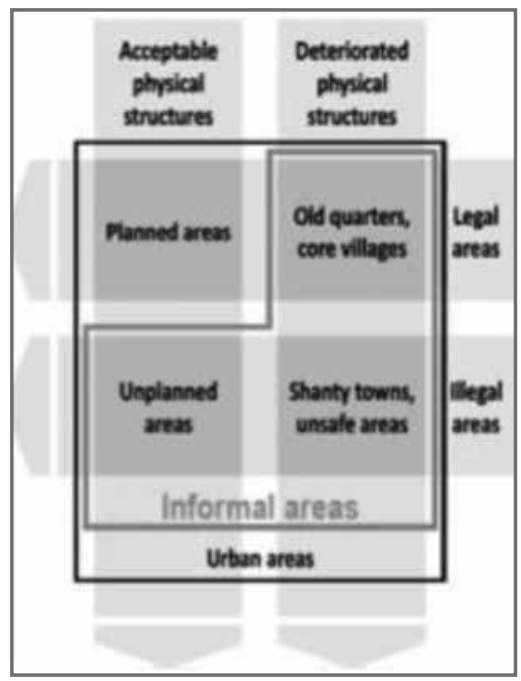

Figure 1: 2008 ISDF categorisation of informal areas. $^{3}$

It is estimated that over $65 \%$ of the Greater Cairo Region population resides in precarious housing in slums and squatter settlements ${ }^{4}, 80-90 \%$ of which are in good condition while the rest are totally deteriorated. The Egyptian revolution may have exacerbated poor housing conditions for some families, as they were evicted and forced into inadequate temporary camps, likely under the guise of the unsafe conditions of their former housing. ${ }^{5}$ Based on such facts, it is clear that the problem of the informal settlements is not confined simply to a housing matter, but should also take into account other socio-economic issues and all aspects relating to the living conditions of the local residents and even the surrounding people and localities.

Housing and health are fundamentally linked. Individuals who are unstably or poorly housed are more vulnerable to infectious diseases, physical violence, and injury. Housing represents a fundamental cause or social condition that leads to health disparities. In order to survive, some residents engage in unhealthy and risky behaviours such as alcohol, drug use, and risky sexual behaviour (e.g. exchanging sex for money, drugs, or a place to stay). ${ }^{6}$ Light was cast on the informal areas in the 1990s, revealing them as a security threat: subversive

3. Abdelhalim, 2010.

4. Levinson 2004, Encyclopedia of Homelessness.

5. http://cairofrombelow.org/2012/10/10/the-health-of-cairos-urban-poorhousing-is-health-care/

6. http://cairofrombelow.org/2012/10/10/the-health-of-cairos-urban-poorhousing-is-health-care/ 
Islamic activists were in near-total control of some of these areas. The Egyptian government then gave due attention to this issue in the policy and legislative framework, allocation of resources, and development strategies. Then, it became a humanitarian cause by the presidential decree for the "right for infrastructure" when upgrading consolidated informal areas (access and roads). Planning the fringes of the cities (mainly Cairo) for the containment of the informal growth also took place. Urban upgrading was part of the 5-year plans from 2002-2007 and 2008-2012. In the 2000s a series of national upgrading programmes emerged, particularly for infrastructures, services, and street widening. However, informal areas were later left for self-improvement by their own residents. Meanwhile, all governmental responses were based on eradication, rehabilitation, or buffering-isolation. These three physical approaches are highly criticised for not including local inhabitants in the process. The programmes divided the bare minimum living conditions into 5 main processes: upgrading; sectorial upgrading; planning and partial adjustment; on-site redevelopment of informal areas; redevelopment and relocation. ${ }^{7}$

To summarise, upgrading included servicing (physical infrastructure/basic public services), improving access to the area, paving and lighting main roads, installing or upgrading solid waste collection systems, constructing/upgrading public services (school, health clinics, bakeries, youth centres, police and fire fighting stations), and, organising street markets and microbus stops. Sectorial Upgrading included programmes focused on smaller size projects in specific areas and targeting the physical part of the corporate social responsibility. Micro-credit schemes and health awareness programmes, educational/health and community facilitation were targeted. Planning and partial adjustments programmes included urban planning, widening main streets, creating vacant lands for public services, and relocation of some houses, leaving the areas to gradual self-improvement, in addition to improved traffic and transport and land value. On-site development included complete replacement of the physical fabric through gradual demolition and in-site construction of alternative housing. This targets highly deteriorated, irregular, and unsafe illegal tenure. Redevelopment and relocation programmes focused on the demolition of slum pockets and social relocation of residents. New housing developments at the city fringes or in new cities have been mushrooming for more than a decade. This targets real estate businesses and commercial interest.

Despite such programmes, one can argue that informal areas are gradually increasing and that such practices were not the best ways to tackle the problem. Examples from different countries affirm that

7. Abdelhalim, 2010. 
the solution is not about buffering, rehabilitation, or working with informal settlements as blight. Despite the factual increase in poverty, unemployment, and inhumane living conditions, most informal inhabitants refuse to leave their settlements and reject proposed rehabilitation projects.

The impairment of the Mubarak's regime is not limited to urban deterioration and marginalisation for the urban poor. However, it has developed a stereotypical "negative talk" that has consequently led to what can be described as class polarisation. Media and cinema describe informal areas as threats to security and a burden on the Cairene society. This aspect has in turn caused a vulnerable selfperception of the informal inhabitants, - despair and mistrust - loss of faith in any developmental efforts and towards the "formal other". How can any community involvement be achieved then? And what happens to the informal settlement inhabitants when they constantly see themselves presented in a very miserable way? Is it true that informal areas are threatening bombs, responsible for the crime and violence in the Cairene society? The fact is, there is a degrading perception from the formal districts of the city to their everyday face-to-face partners of marginal yet indispensable jobs: maids, drivers, cafe waiters, and $50 \%$ of governmental employees. Cairo society seems to evidence a paradoxical phenomenon in the relationship between subcultures; massively crawling over the formal face of Cairo: "A phenomenological conundrum", "informal culturation" or "informalisation" accompanied by a greater spread of urban poverty. This is believed to prohibit any developmental plan. Moreover, there has been some newly emerged behaviour in Egyptian streets emphasising this "them and us" phenomenon. Some of such behaviours are accepted (graffiti and street performances), while others are not (violence and sexual harassment).

\section{THE URBAN DIMENSION OF THE REVOLUTION: JANUARY 2011 - JUNE 2013}

According to Castells, "the city is not a framework - but a social practice in constant flux, the more it becomes an issue, the more it is a source of contradictions, and the more its social manipulation is limited to the ensemble of social and political conflicts". ${ }^{8}$ For that, the political incidents concomitant with the January 2011 revolution until June 2013 in Egypt as "flux" had the ultimate effect on the social practices. Many of the long-denied and marginalised urban poor have contributed and expressed themselves in the hearts of the large and the mid-sized cities and did not limit their urges to the political removal

8. Castells, 1977. 
of the regime ${ }^{9}$. Rather, through their persistence and lingering in the squares, they have demonstrated what can be called a "Revolution of the Urban Poor: Here to Stay".

January 2011 revolution's motto was about three basic human needs the urban poor are deprived of: (bread); freedom of expression (freedom); and fulfilment of human needs (social justice and dignity). After the revolution, presidential campaigns started in the second half of 2011. Upgrading informal areas has been a main objective on every candidate's list in 2012. Upon the declaration of the Muslim Brotherhood's Mohamed Morsi as president in June 2012, slogans of "towards a better Egypt" were commonly heard. On top of these were the strategic priorities: social justice, eradication of poverty, and economic development as national projects. More associated slogans were human development (capacity building), social enablement, health care, education and scientific research, technical training, social justice, dealing with unemployment, and the eradication of poverty and inflation. Since the revolution, several independent campaigns were launched to develop/upgrade informal areas by creating better living/housing areas for their inhabitants, raising more slogans of human shelter as a basic need and a clean environment as a requisite for all citizens. However, it is believed that the presidential bill was exaggerated, and incredible increases in the poverty rate, unawareness, unemployment, amplification of inhumane living conditions and pollution have accompanied economic worsening over a span of only one year (June 2012-June 2013). The long-suppressed citizens have also demonstrated poor conduct and integrity, where harassment, aggression, and rivalry became normal street practices until the June $30^{\text {th }}$ Egypt's second revolution and the ousting of Morsi.

\section{POSITION OF ARCHITECTURE SCHOOLS FROM NATIONAL STRATEGIES \& PLANS}

After two tides of the revolution and the dawn of a new Egypt, isn't it high time to work on the eradication of urban poverty? Isn't it high time to draw a new urban map of Egypt without traces of informality? From our position as educators, moving design education to meet such a challenge and contribute to the establishment of a sustainable thinking paradigm appears as priority in this transitional phase.

This raises some questions: can the design profession meet the enormous ethical and intellectual responsibilities required to achieve sustainable design work? In the meantime, what would be the objectives, content, and methodology of design education to allow architecture

9. http://issuu.com/clustercairo/docs/archiving the city in flux 
students and fresh graduates to meet their expected roles? What is the suitable phase of education to introduce the students to such issues?

Methods and tools of experiential learning have been shown to be keys for developing an educational framework that extends students' abilities to achieve sustainable design work when dealing with informal areas. These abilities may then be implemented from the onset of their architectural education.

In this regard, five principles characterise the processes: start with knowing where you are; trace the footprint and follow the flow, through human and ecological principles and through analysis of the existing environment; design with nature; everyone participates in design, not just design professionals; learn from what you have designed and share this new knowledge.

With such facts and figures, why is such a national problem not a core educational pivot? Why do we include utopic urban design and absolute housing and community design without implanting the issue of eradication of urban poverty in the curricula? The topic is not only confined to urban and housing design. It is political, economic, educational, health-related and several other issues. If we are aiming for a better Egypt, we should focus on dealing with our own problems prior to teaching foreign and international utopic images in our schools. A decent quality of life should be the core of our entire curricula in all our educational institutions. However, it is not expected that developing an educational programme will help eradicate the problem of informal areas in Egypt. Nevertheless, it is hoped to implant a humane dimension within the city, through the acceptance and development of informal areas to be more lively, safe, attractive, sustainable and healthy portions of the built environment.

Taking a look at the existing programmes for both the undergraduate and postgraduate programmes in most of our Egyptian architecture and urban design schools sadly reveals a general lack of informal urbanism as an independent topic in the curricula. However, there are some case studies that tackle the issue in design, housing, community design, and some other courses. In the faculties of urban and regional planning, and in the faculty of Engineering of Cairo University, the terms "upgrading, community design, informal areas" do appear in undergraduate courses as case studies.

Except for a few case studies in the housing and urban design taught by professors Rowaida Kamel, Hisham Bahgat, Sahar Ateya, Mo'taz Farid and a few others, most of the schools teach city planning and urban design courses with a conceptual duality: theoretical city planning lectures and urban design assigned projects are under one course name. This produces a gap between the knowledge offered 
in the undergraduate courses and the methods of application after graduation gained from this knowledge. Students and fresh graduates cannot actually deal with the unpredictable and uncontrollable growth of the city.

Here, there are three major problems:

- Mostly, the planning approach is purely physical, and does not take into consideration the local community.

- When considering people in the process, no true participation or actual involvement of the local communities, stakeholders, decision makers, NGOs, practitioners and governmental bodies, etc., appear in the curriculum design, or final assessment of the courses.

- Handling the problem is commonly done from a utopic design approach, without even criticising or developing the governmental solutions.

A review of the programmes in our Egyptian schools reflect that some terms appear in the titles and contents of the courses, such as ecology, economy, social context, cultural background, governance, participation, and urban sociology. Meanwhile, other terms totally disappear, such as sociology, environmental behavioral studies, psychology, anthropology, action (participatory), research for urban design, and participation theories and techniques.

However, there are few graduate programmes tackling related issues, such as the IUSD (Integrated Urbanism \& Sustainable Design), a 4-semester programme developed between Stuttgart and Ain Shams Universities in collaboration with DAAD, GIZ, and CEDARE. ${ }^{10}$ The programme encompasses topics and terms of geography, sociology, cultural studies, political sciences, and urban economics. The objectives stated are to provide expertise in the field of participatory planning and building, energy efficient construction, integrated aspects of landscape, infrastructure planning, urban management and governance. The focus is ecology-oriented with a social approach. Another programme is the 4-semester M.Sc. of the TUB-Gouna, in collaboration with DAAD, and German higher institutions. ${ }^{11}$ One of its three titles is "Urban Development". Its stated objectives are to enhance urban productivity, develop knowledge, methodology and skills, and to enhance sustainable urban development. The focus is on socioeconomic and environmental conditions and conflicts. The content is related to architecture, urban planning, landscape architecture, regional planning, and civil engineering. One other programme is the Sustainable Development Diploma and M. Sc. offered by the American

10. http://www.iusd.uni-stuttgart.de

11. http://www.campus-elgouna.tu-berlin.de/menue/academics/ 
University in Cairo (AUC). ${ }^{12}$ It has international partners such as the RWTH Aacher University, German, Politecnico di Milano, Italy, and the Graz University of Technology, Austria. Its objective is to equip social entrepreneurs with comprehensive skills that will allow them to start up green business, launch innovative ventures and products, and put public policy and social entrepreneurship innovations in place. It focuses on addressing society's most pressing environmental and natural resource challenges while balancing social concerns and economic feasibility. The programme relies on a sound theoretical and practical understanding of sustainable development in all three sectors; private, governmental and non-profit in preparation for careers in a large range of organisations. Despite the fact that the modules offered are related to green technologies, entrepreneurship, sustainable cities, and sustainable communities, factual governmental urban design practices do not directly benefit from such programmes. It is my insistence that a tailored programme for the development and upgrading of informal areas is severely needed. For that, I insist that architecture and urban design schools should refer to the education charters recommended for architecture education, such as the UNESCO-UIA the RIBA and others who are concerned with underdeveloped and developing countries. Reading through those charters affirms that national problems should be the foundations of curriculum design. This also calls for a fresh look at the best practices that emphasise social justice - particularly regarding urban and housing policies - which in turn suggests the design of a tailored course for dealing with informal areas in each and every school of architecture and urban design in Egypt.

\section{A NEW PERSPECTIVE}

The 'informals' are normal Egyptians who chose to live in cheaper, or closer locations to their jobs and transportation facilities. Some of them are second or third-generation immigrants from rural areas. Informal inhabitants are pillars of Egypt's everyday life and part of national economy. The other side of image is not that dark; Informal areas possess positive features too. According to Dina Shehayeb, there are six main virtues for informal areas: self-efficiency, work-home proximity, walkability, participation, my-street-my-home, sense of safety, and social solidarity. ${ }^{13}$ In addition, there are some improvised creative built-environment features such as eco-friendly and recycling solutions. Khaled Abdelhalim adds more potential, stressing the livework-service, the high economic value, informal real estate assets

12. http://www.aucegypt.edu/academics/grad/sustainabledevelopment/ Pages/default.aspx

13. Shehayeb, 2009. 
and taxes, and crafts and small industries production. All of these advantages could be harnessed as cornerstones for informal areas' urban sustainability. ${ }^{14}$

Considering those positive features, we need to have a base to start the design of the proposed programme. International best practices to learn from are numerous. I categorise them here into: global visions and objectives; professional practices; personal experiences; inspiring examples.

The basic source for drawing the vision, mission, and objectives would be the UNDP Millennium Development Goals of 2000-2015 including: eradication of extreme poverty and hunger, universal primary education, promoting gender equality and empower women, reducing child mortality, improving maternal health, combating contagious diseases, ensuring environmental sustainability and, developing a global partnership for development. ${ }^{15}$ On the same line, the UNESCO/ UIA charter of the Architecture Education 1996-2005, stresses that "A Decent Quality of Life" for all inhabitants of human settlements is the ultimate objective of architectural education. These are to be achieved through scientific and technological applications, social, economic, cultural and aesthetic needs, ecological balance and sustainable development of the built environment.

Another source might be the professional practices learned from the World Bank, United Nations Organisations (Habitat, UNICEF, and UNDP) and other bilateral donors such as SIDA, DFID, GTZ, CIDA, and USAID. These emphasise the importance of community involvement in developmental projects. An example of professional practices is the AgaKhan Historic Cities Support programme, among others, to inspire strategies, action plans, and experiences for incorporating participatory techniques in the process.

However, for my educational model, and based on personal involvement with an Egyptian NGO that worked with the GIZ, I have chosen the Participatory Development Programme (PDP). The Ministry of Economic Development has been implementing the Participatory Development Programme in Urban Areas (PDP) over the last 15 years. ${ }^{16}$ The programme has developed methods for participatory upgrading based on the Egyptian and international experiences. It also has pilot projects in several areas in the Greater Cairo Region, with several publications regarded as methodical references for both education and practice.

14. Abdelhalim, 2010.

15. http://www.un.org/millenniumgoals/

16. Supported by the KfW Entwicklungbank (German Development Bank) and the German Technical Cooperation "GTZ" (Currently the GIZ) and financed by the German Federal Ministry of Economic Cooperation and Development (BMZ). 
The third source for the best practices to build on is an undergraduate model I have developed over my two decades of teaching experience, and which I'm implementing on an individual basis. ${ }^{17}$

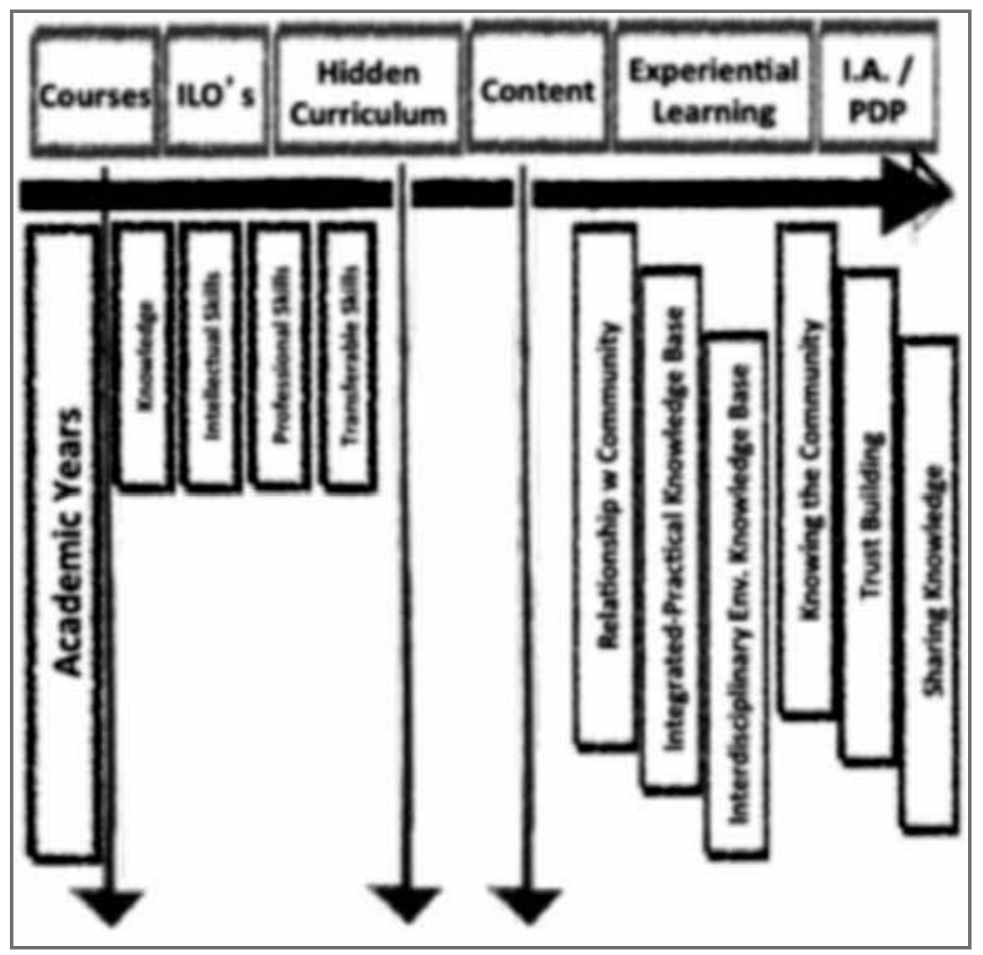

Figure 2: Model Structure

17. Based on personal affiliation as Associate Professor and Program Coordinator, Department of Architecture, Misr International University (MIU). 


\begin{tabular}{|l|l|l|}
\hline \multicolumn{1}{|c|}{ Year } & \multicolumn{1}{|c|}{ Course } & \multicolumn{1}{c|}{ Objective } \\
\hline Second & $\begin{array}{l}\text { Human Factors in } \\
\text { Design }\end{array}$ & $\begin{array}{l}\text { Development a scientific } \\
\text { understanding of a human } \\
\text { association within its true setting }\end{array}$ \\
\hline Third & $\begin{array}{l}\text { Design Methods \& } \\
\text { Research }\end{array}$ & $\begin{array}{l}\text { Engaging students with informal } \\
\text { community in true action research }\end{array}$ \\
\hline Fourth & $\begin{array}{l}\text { Socio-Behavioural } \\
\text { Studies in Architecture } \\
\text { \& Urban /design }\end{array}$ & $\begin{array}{l}\text { Predicting and analysing the } \\
\text { trilogy of Culture as user groups } \\
\text { behavioural patterns and physical } \\
\text { settings in forming a culture of a } \\
\text { place }\end{array}$ \\
\hline Fifth & $\begin{array}{l}\text { Participatory Design } \\
\text { Theories Techniques }\end{array}$ & $\begin{array}{l}\text { Endorsing the role of the } \\
\text { architect as facilitator and urban } \\
\text { development through participation }\end{array}$ \\
\hline
\end{tabular}

Figure 3: Courses Objectives.

The model is structured such that the courses cover a span of four academic years, adhering to the general programme-intended learning outcomes, with a parallel hidden curriculum related to the national problem of informality. Hence, the flexible content encompasses global theories and concepts, but the case studies vary from one course to the other and from academic year to the next. Course practices adopt the experiential learning approach, where the built environment is an open textbook.

My focus here is on the third and fourth courses that are offered in the pre-senior and senior academic years with direct student involvement and hands-on experience in informal areas. With respect to the SocioBehavioural Studies course, the hidden curriculum shifts the students' perception of "the other" and leads them to include the reactions of various groups in the formation of their plans. It also enables them to respond directly to the requirements of their community and contribute in an ultimate political process. Consequently, students are then expected to be aware of the inherent value judgments of any contributions they make to the process. Such involvement seeks to employ many levels of participation, such as: knowing the community from the students' perspective, building mutual trust, and sharing knowledge between both sides. 


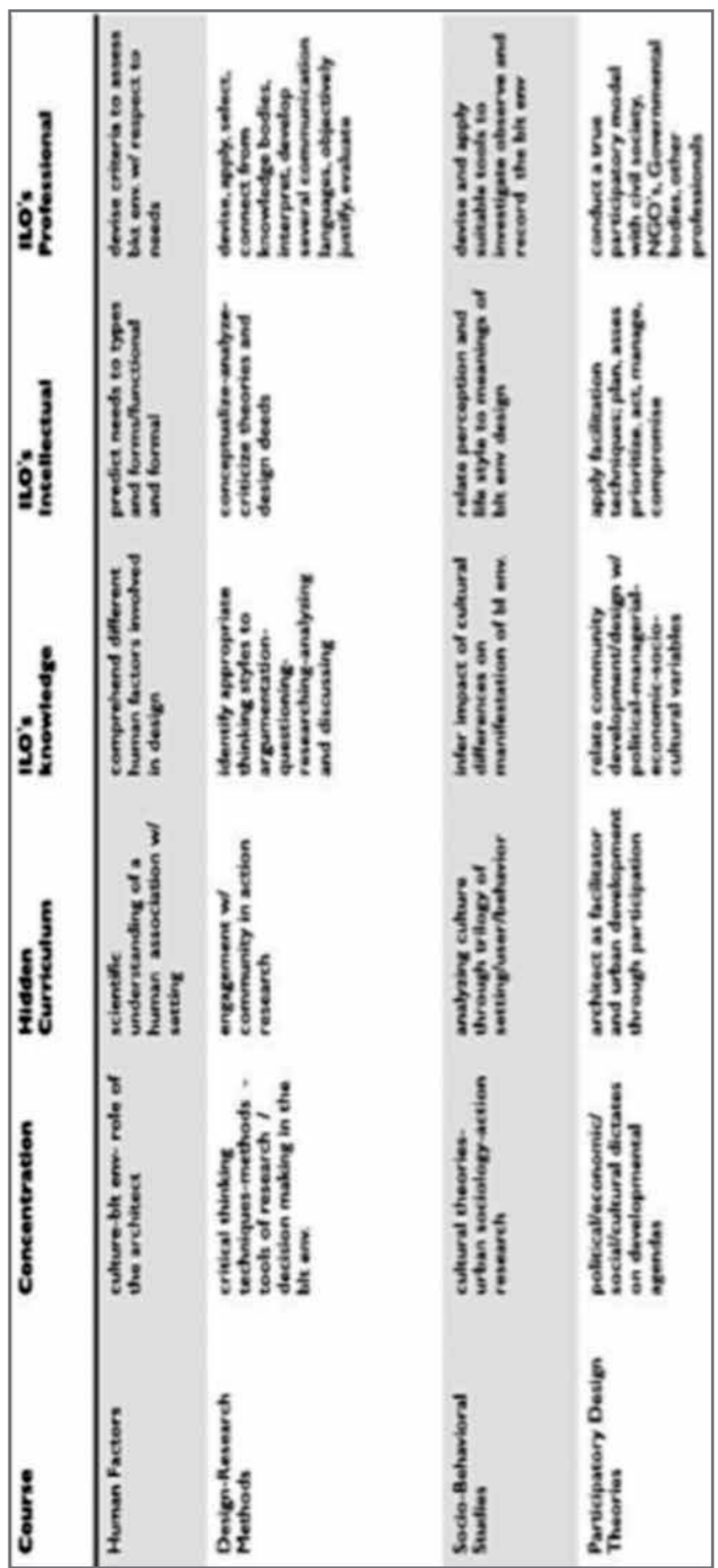

Figure 4: Content and intended learning outcomes of the courses. 


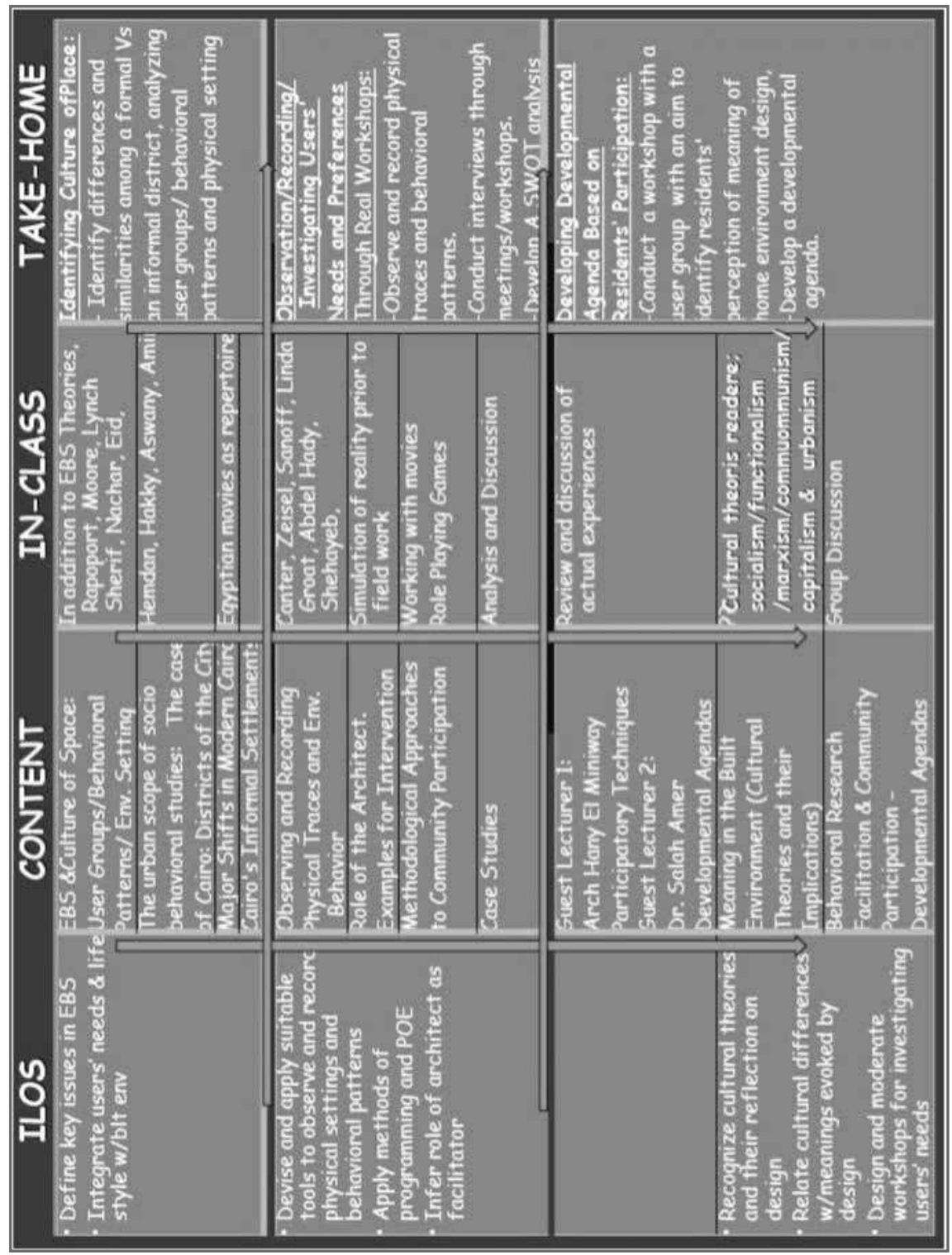

Figure 5: Socio-Behavioural course structure. ${ }^{18}$

18. Safey Eldeen, 2009. 

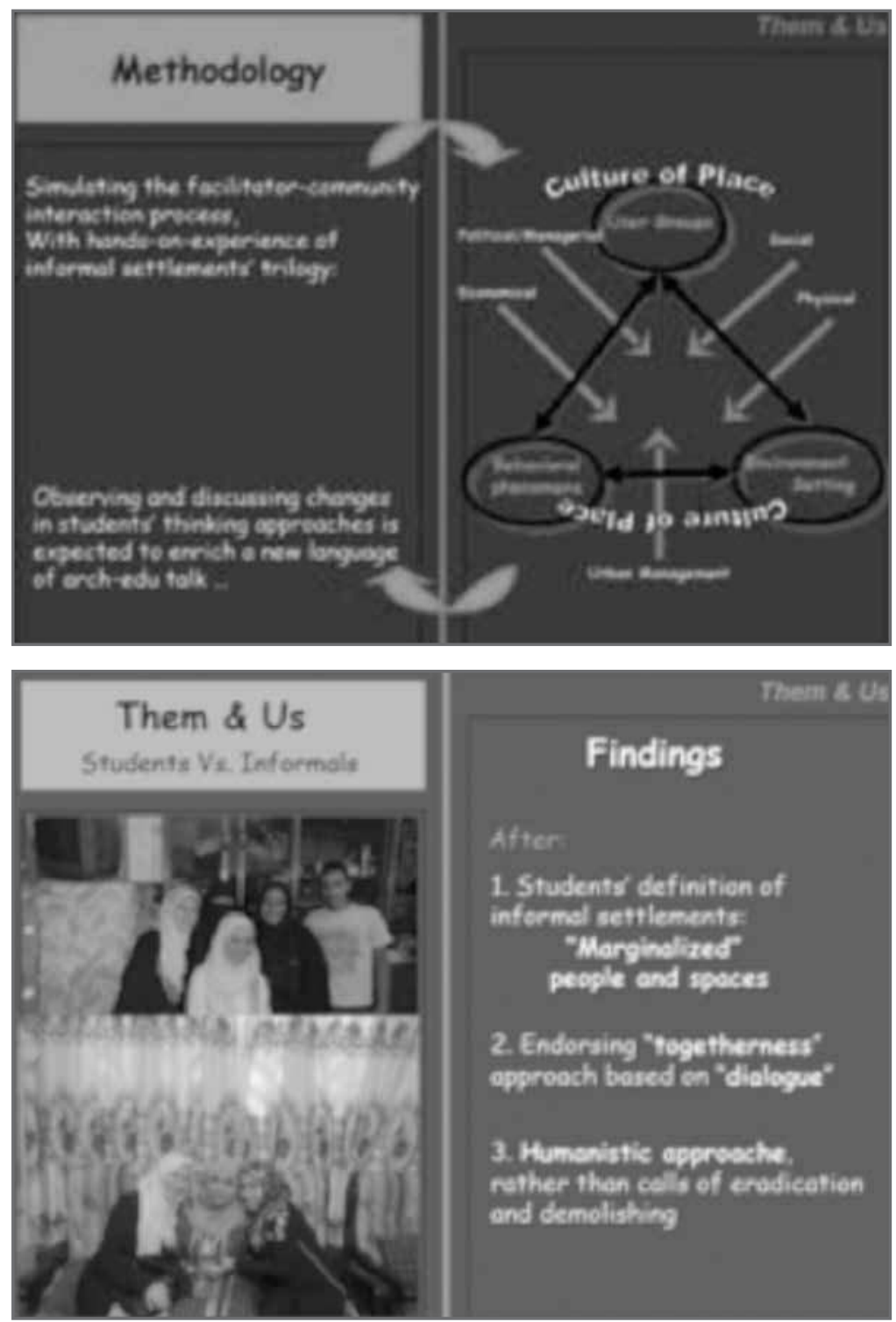

Figure 6: Methodology and findings of the course. ${ }^{19}$

19. Safey Eldeen, 2009. 
In such a case, students are supposed to establish and sustain a multi-sided and relatively long-term relationship (12-15 weeks) with a human association in its natural setting for the purpose of developing a scientific understanding and for the sake of changing their concept of the "other". Students share with their community its direct observation, semi-structured interviews, brainstorming, and prioritising sessions. Moreover, they go through assignments of mapping, measurements, diagramming, gaming, and role-playing. According to the work requirements, both groups and individuals are also worked on. Such course structure is highlighted as follows:

Later, in the academic year, comes a specific/particular upgrading of an informal area through the course of Participatory Design Theories and Techniques, designed collaboratively between faculties, practicing professionals tested and developed among students: the course is a real life manifestation of all studied theories, concepts, methods, tools, and applications. 


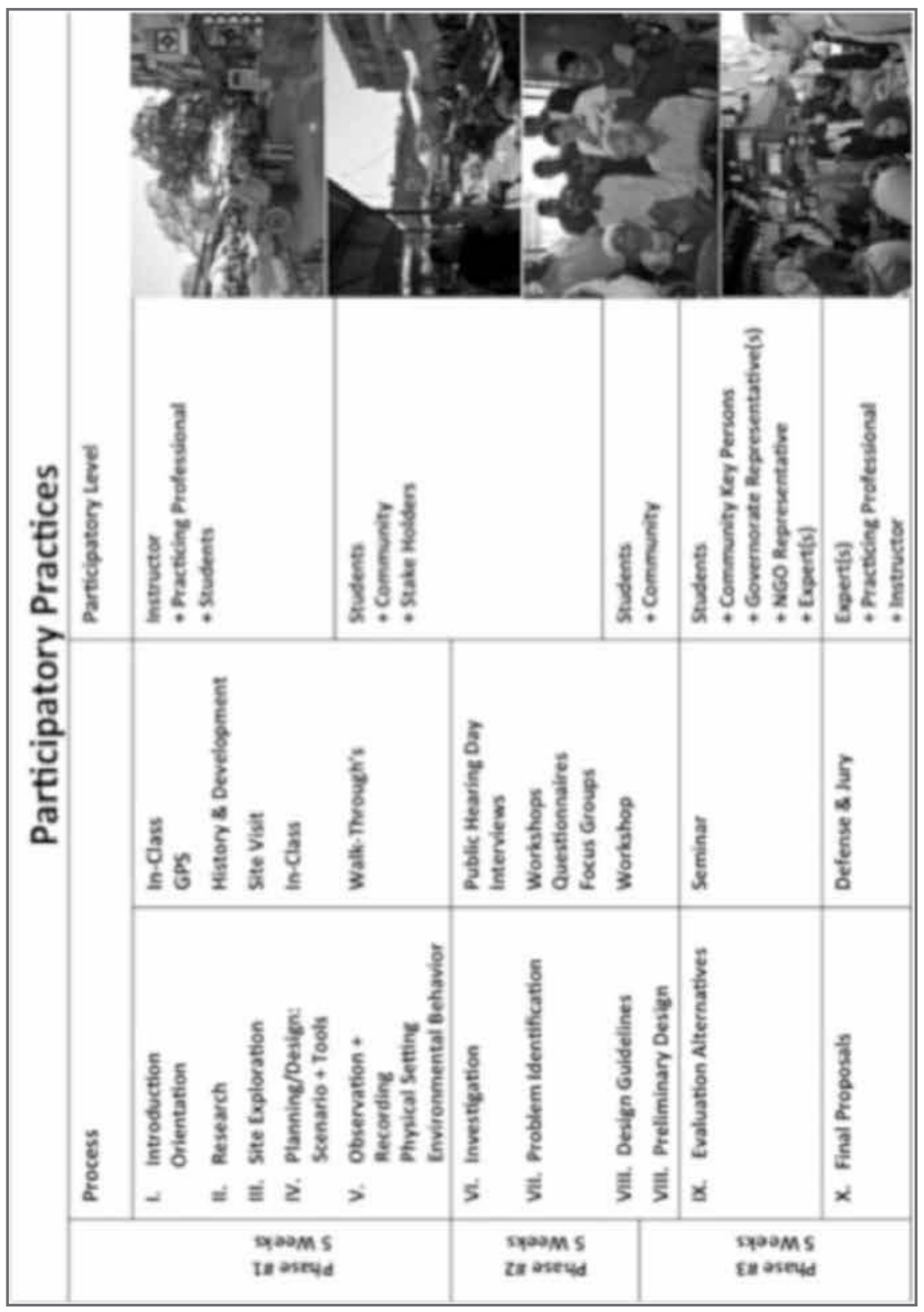

Figure 7: Participatory Design Methods and Techniques course design. ${ }^{20}$

20. Safey Eldeen, 2012. 


\section{STUDENTS' REFLECTIONS}

Considering that our students represent the "crème" of the society (they can afford to enrol in private university) and had no earlier connection or communication with informal areas, to them, informal inhabitants were "the unwanted other". Introducing the course, the students had a stereotypical misunderstanding of the meaning of the term "informal settlements" - literally the word "a'shwaa'eyat". For them, it meant just a "poor district". Pointing out the term "those people", it was obvious that many students do believe that the main reason of all the problems of the informal settlements is the inhabitants themselves who are described as doing nothing to improve their standard of living. Moreover, some students thought that the migrants who came from different rural areas to settle in Cairo in those informal settlements should have not migrated, as they had better lives in their homelands.

Some students barely knew about informal areas until the "Dîwîa" landslide in 2008. For them, informal settlements were associated with terrorism, drug dealing, harassment and other criminal behaviour as seen in the movies that represent a "dark side". Accordingly, their idea of working with that informal "other" was frightful. After dealing with informal settlements, students were shocked by the physical conditions, proved to be worse than the preconceptions they had formed from movies. As for the user-groups, students were astonished to find educated people, governmental employees, and university students living there. Cooperation and solidarity were the major students' findings of the dominant behavioural patterns. Students suggested that this was basically due to cultural backgrounds, common agony, and lack of privacy in the physical settings, adding new dimensions to values embedded in the informal settlements" "sub"-culture.

Actually, students laid hands on the informal inhabitants' viewpoints of the formal "others" through their revealing their lack of trust, asserting that the government ignores their existence. Rivalry was reflected in some cases of the communities' aggressive behaviour towards the students and refusal to share information with them. However, some inhabitants' sense of pride led to their pretentious attitude of equality with the students, as if there were no differences between them. In fact, most of the students realised that informal settlement inhabitants live lives similar to their own, as one student sarcastically put it: "They eat food and do drugs, just like people in Maadi and Zamalek do, the only difference is that in informal areas they eat cheap local food, and use cheap kinds of drugs while in formal areas there is a high quality of both food and drugs!". 
By the end of the courses, the students agreed that the informal areas are marginalised in more than one sense because of the government and the media. However, they suggested that this marginalisation and physical/social exclusion is an aspect that has to be overcome by endorsing more dialogue between formal and informal parties, changing their negative images in the media and better representation of their culture in the cinema, tantamount to addressing development in more humanistic approaches rather than calls of eradication and demolishing. Discussing the urban proposals in the last phase of the participatory design course, students had to deal with governmental representatives. This endeavour has introduced the students to various governmental mindsets and showed them the real obstacles in verifying their designs. They have learned about low budgets, administrative priorities, and national security measures that might hinder community participation in real life.

However, the participatory "re"-design process proved that:

- Learning is social, where learning takes the form of indirect interactions.

- Thinking involves looking into our experiences, connecting them with our feelings and attending to our theories in use, where abstract conceptualisations become something one can analyse and work on.

- Theories studied become leading ideas, allowing the development of further responses and moves.

- A repertoire of images, ideas, examples, and actions is then developed, from which we draw upon in a new situation.

- Communicating ideas challenges our anxieties at the same time. Enthusiasm and a change in attitude towards the encounters takes place while endorsing a sense of responsibility as well as developing creative thinking abilities.

Different types of assessments are conducted upon the completion of the courses. Students evaluate the courses and the instructors. The external evaluators' assessment, if positive, indicates successful teaching and learning practices, and the achievement of their intended learning outcomes as stated in the programme and approved by the different quality assurance bodies that review the programme and courses regularly. Moreover, feedback reports from outsider practitioners and professionals, guest lecturers, juries, or different real-assigned project representatives also accentuate on achieving the intended learning outcomes of the courses. Several evaluation methods were conducted to examine and asses the achievement of model objectives, as well as the validity of the experiential model of teaching and learning, while touching on the informal settlements challenges agenda. 


\section{A STRATEGIC FRAMEWORK: WHAT, WHY, WHO AND HOW?}

According to Castells, "Urban planning must be interpreted on the basis of the social effect produced by the political instance in the urban system and/or in the social structure". ${ }^{21}$ "Each 'urban struggle' must have its structural content specified, and be considered in terms of the role it plays vis-à-vis the various social classes involved. Then and only then will we know what we are talking about". In another reference, Castells adds: "We need an educational social movement in the urban field. By social movements we mean a certain type of organisation of social practices, the logic of whose development contradicts the institutionally dominant social logic". ${ }^{22}$

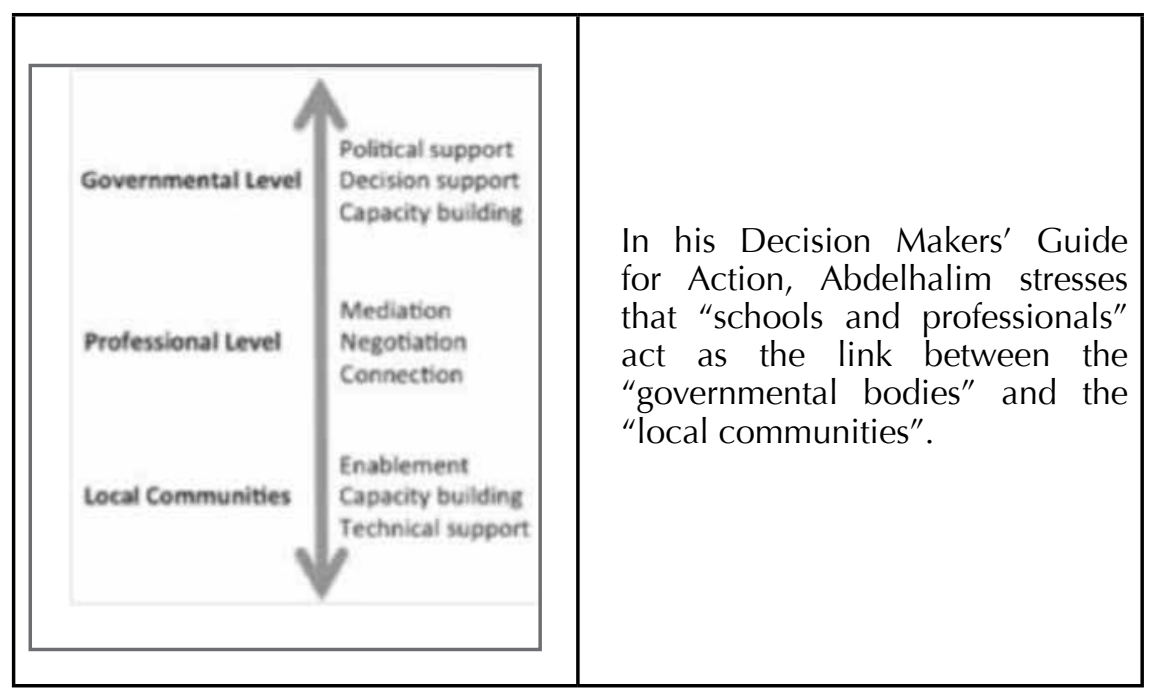

Figure 8: Levels, roles and responsibilities for informal areas' developmental agenda. ${ }^{23}$

Agreeing with Castells, and based on AbdelHalim, my proposed framework is for an urban renewal programme based on a true silenced public outcry: it concerns an already structured social space, of which it changes the form, the social content and/or function. It is based on public initiative, whatever the legal or financial form of the renewal agency, where private enterprise may take over the work.

21. Castells, 1972.

22. Castells, 1977.

23. Abdelhalim, 2010. 
Hence, conventional theories, concepts and terms are all to be revisited. The new educational paradigm should cause students to understand the link between the designer's anticipation and actual use, away from the inherited designer's deterministic attitude shaped by a long tradition in the profession. Rather, students should determine reactions of various groups and respond directly to the requirements of community culture.

"Decision Making Guide for Action" is once again a basic reference for the what, why, how, and who of dealing with informal areas in Egypt. ${ }^{24}$ It summarises the PDP approach, which I believe the most suitable sources for designing the philosophy and vision of my proposed postgraduate programme framework. Such approach complies with the UNDP millennium objectives and the Architecture Education charters.

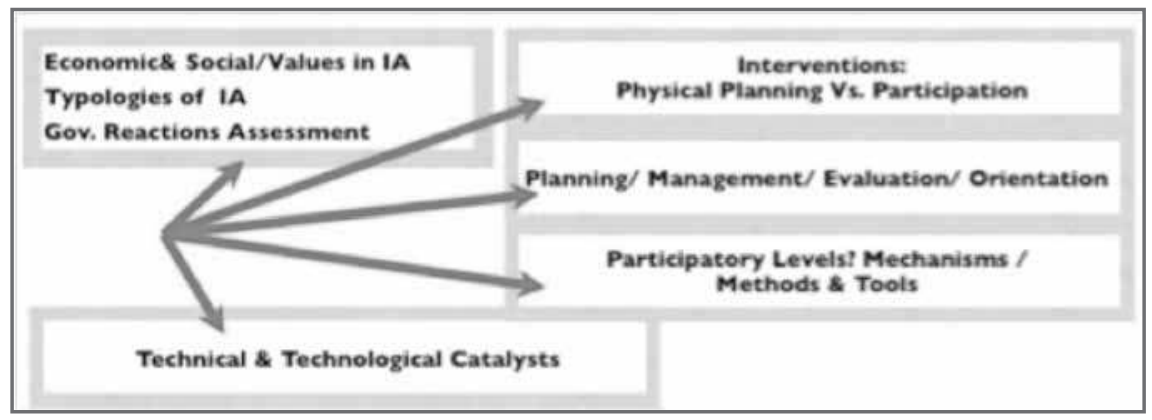

Figure 9: Decision making guide for action core topics.

Accordingly, the proposed model can be based on:

- Stating pivotal key concepts.

- Choosing cores and concentrations of the programme.

- Signifying considerations of devising the model, including the values and ethics to be embedded in the programme, and on which methodology they will be drawn.

- Identifying the stakeholders of the programmes and their roles.

- Developing the overall structure.

Consequently, the model should be based on practicing the social use of architecture, making people visible in the process: a real involvement with informal areas, working off campus, live upgrading developmental projects, professionals from different disciplines, communication and teamwork, transferrable skills (argumentation/justification and persuasion), action research (with civil society in informal areas),

24. Abdelhalim, 2010. 
facilitation and participation (workshops through public hearing days and focus groups), community consensual decisions, strategic plans, and action plans.

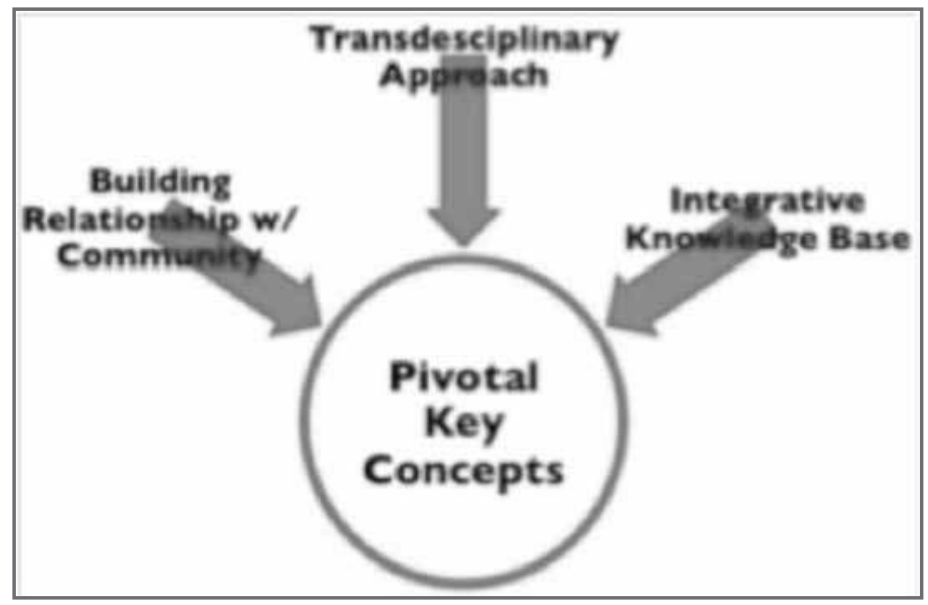

Figure 10: Programme pivotal key concepts (the "what" of the programme).

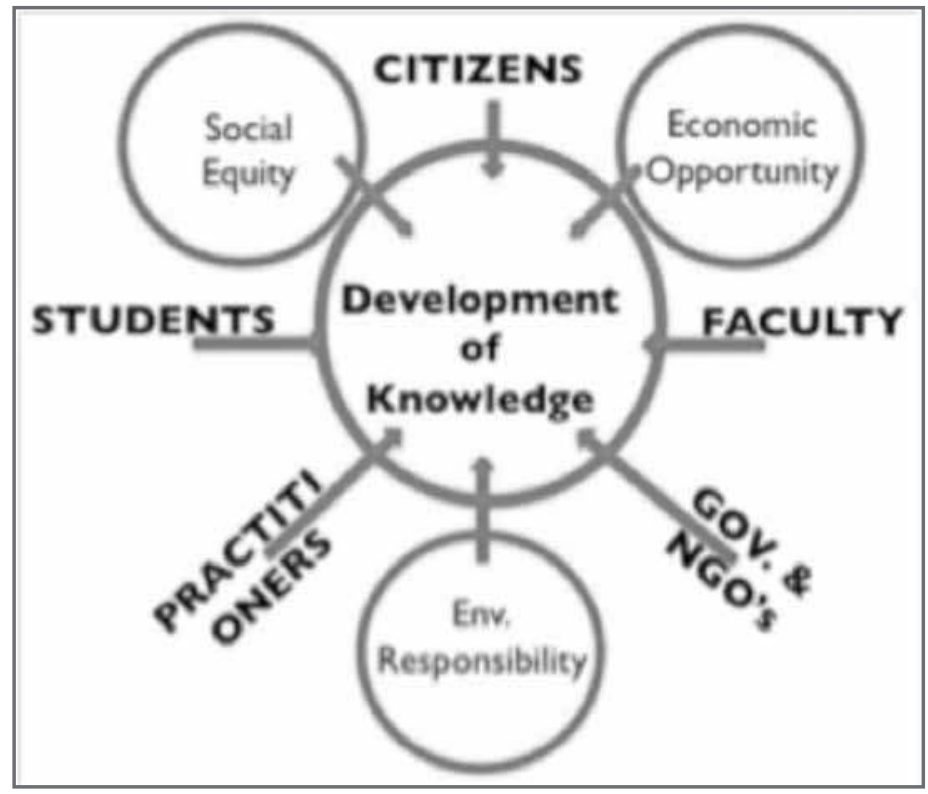

Figure 11: Programme aim (the "why" of the programme). 
The model should be essentially based on the three elected pivotal new concepts: building relationships with the community, a transdisciplinary approach and the integrative knowledge base.

Such pivotal key concepts will help achieve the ultimate goal and core of the programme, which is the development of knowledge regarding social equity, economic opportunity, and environmental responsibility. The content is to be designed by the involvement of its stakeholders: citizens, Government, NGO's, practitioners, altogether with faculty and students.

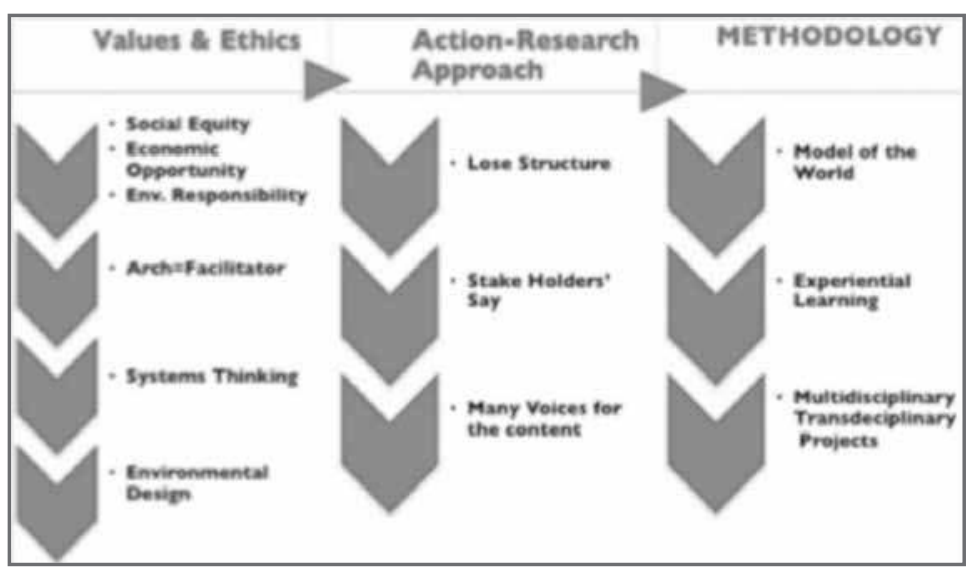

Figure 12: Values and ethics base for methodology (the how of the programme).

The main aspects of the programme would then become the main values on which the core programme practice would revolve. In addition, academic "ethics" of facilitation, systems thinking, and environmental design are also cornerstones. Demonstrations of such values and ethics would then call for the design of an action-research approach referred to as participatory research. The content should always be adaptable to local problems and stakeholder needs. This implies that the case studies and their approaches are not fixed; they change according to the nature of the problem at hand. Accordingly, there should be many voices involved in the design and the offering of the programme. Such a programme would be a simulation of the real world. An application of an experiential learning model is expected to include multidisciplinary and interdisciplinary urban practices. 


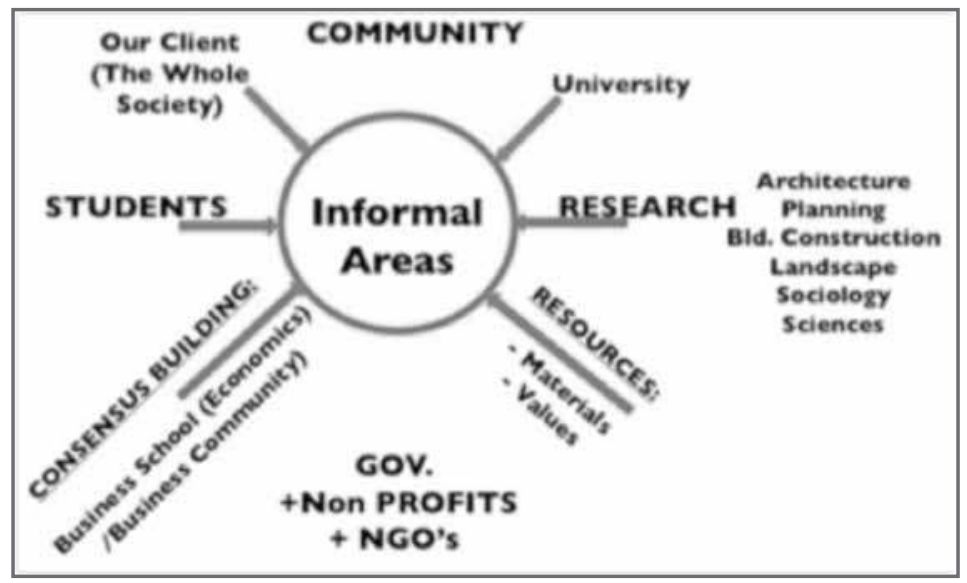

Figure 13: Groups involved in the verification (the "who" of the programme).

\section{DISCUSSION}

It is argued that such a model will help change several academic and professional conceptions:

With respect to the Urban Development of Informal Settlements in Cairo:

- True exclusion and marginalisation dominates the relationship between formal and informal Cairenes.

- The phenomenon of informal cultivation or informality is speedily threatening the urban face of Cairo.

- A gap does exist between policies and efforts claimed by the governmental development agendas and the true pace/quality/ volume of development.

- There proved to be some values in the "culture of place" theory (user groups-physical settings-behavioural patterns) of informal settlements that can act as cornerstones for their sustainable urban development.

With respect to the Experiential Learning Approach model adopted:

- Simulation of real world situations can be achieved through different in-class practices, such as gaming, role playing, the use of multi-media such as by reviewing movies with settings or concepts related to those taught, observed, and reflected upon.

- Reflection-in-action and reflection-on-action do transform the learning process into a change in attitude.

- Learning as a social activity provides students with hands-on experience faster and deeper. 
- The instructor's role becomes more that of an advisor rather than that of an authoritative figure.

With respect to the importance of environmental behavioural studies as a pivot of architectural education:

- Education becomes more humanised and ethical, respecting the differences and bridging the gap of otherness, leading to democratic communication between architects and the informal inhabitants.

- A change in perception towards the role of the architect automatically changes into the "facilitator".

- Proposal of Urban Sociology concepts, assigning other readers beside architectural ones, and utilising Egyptian cinema as a repertoire to consolidate students' mental schemata towards the multi and trans-disciplinarily nature of architecture.

Based on the preceding, we can now move to visualising the impact of such a model of postgraduate urban education on urban practices. In turn, informal strategic priorities for urban areas are as follows:

As a start, a quick reminder of the Informal Areas Urbanism Strategic Priorities "globally agreed upon objectives ${ }^{25}$ suggests the urge of some issues as pivots for the proposed model. These are: sustainable urban development, social inclusion, poverty alleviation, good governance, rights-based approach, decentralisation (including institutionalisation and capacity development). Then, three main urban education hidden curriculum aspects (practicing the social use of architecture, environment-behaviour studies, and experiential off-campus learning will automatically lead to true urban practices (informal areas as positive agents rather than a threatening bomb, community participation and stakeholders' involvement, and participation as key to urban upgrading \& governance)".

Applying such a model is expected to change current urban planning education as follows: ${ }^{26}$

- A demonstration of democratic education and urban practices.

- Drawing in the marginalised individuals and groups into the decision-making procedure of the developmental process in a structured, institutionalised and sustainable way.

- An activation and organisation of the roles of all concerned parties of the development process.

- Paying attention to people's voices and their expression of needs while planning urban management measures.

- An empowerment of the poorest and most marginalised.

25. http://www.un.org/millenniumgoals/

26. Piffero, E., 2010. 
However, whenever applied, the model is highly context-sensitive. Its strategies and methods need to be revisited/reconsidered, in particular with mechanisms devised to work at the district level.

This will help substantiate:

- Internal workable definitions or an agreement of the theories and concepts.

- A deep awareness of the nature of social power.

- A corroboration of theoretical exercises and practical outcomes; a continuous testing of theories in action.

I believe that the implantation of the proposed postgraduate programme is the only way urban education can improve Cairo and Egypt with resilience to political and social changes caused by the upheaval era we are living in.

\section{CONCLUSION}

In response to the complex social, economic, and environmental challenges facing the human habitat worldwide, and in tandem with the Millennium goals, new approaches are needed in order to deal with urban development in informal areas. First, a new approach to the perception of the nature of informal areas is crucial for generating the political and societal will to deal with them. Second, a new approach to urban education needs to be applied on a large scale to make a difference. Third, the promotion of concepts and values and the change of resource management patterns cannot be done without qualified practitioners. With the aim to bridge the gap between education and practice regarding the field of informal areas, this article on informal areas is considered as a consequence of the former regime and the three years that included two revolutions and the Muslim brotherhood rule in between. Light was shed on the position of urban education and its stance towards informal areas as part of a main objective of the national strategic plan. Then, we moved to reviewing different approaches in dealing with informal areas. In this respect, moving design education closer towards contributing to resolving the dilemma of informal areas appears to be one of the most controversial issues ahead of us as educators. Among several questions in debate, questions revolving around the objectives, the content, and the methodologies of this education will allow future architects and urban designers to meet their expected roles.

However, conventional approaches to urban design teaching do not offer future practitioners direct engagement with people and their environment in a way that is crucial for realising potentials and constraints affecting design. Without understanding the realities and 
dynamics of urban development, designers tend to produce solutions that lack balance between environmental, social, and economic aspects. For example, community facilities are usually designed without taking into account the community, its priorities, or without understanding the implications of the design on the mobilisation and management of local resources. It is more efficient to address this pattern during the education of designers rather than re-educating them during their professional practice.

This article argues that a new approach for teaching architecture and urban design using on-the-job training and learning-by-doing methods could bring future professionals more on track. Such an argument is supported by presenting an educational model devised so that students are involved in real-life tasks aiming to develop an experiential learning model that combines knowledge and intellectual skills with analytical, mediation, and presentation skills. The model tackles how practitioners can adopt new roles as honest mediators of local dialogue and negotiation, as well as advisors to local stakeholders on design implications in their community, on the environment, and on urban development.

Finally, the discussion about the model drew on empirical transdisciplinary foundations. This ensures that only a true collaboration between students, representatives of the civil society, political decision-makers, NGOs, and professionals can lead to the liveability, functionality, and ultimately, the sustainability of human habitat. 


\section{GLOSSARY}

CEDARE: Center for Environment and Development for the Arab and Europe

CIDA: Canadian International Development Agency, Egypt

DFID: Department for International Development

GCR: $\quad$ Greater Cairo Region

DAAD: The German Academic Exchange Service

(German: Deutscher Akademischer Austauschdienst)

GIZ: $\quad$ German Society for International Cooperation

(German: Deutsche Gesellschaft für Internationale Zusammenarbeit)

GOPP: General Organization of Physical Planning

GTZ: TheGermanOrganizationforTechnicalCooperation (German: Gesellschaft für Technische Zusammenarbeit)

IA: Informal Area

ISDF: The Informal Settlements Development Facility

PDP: $\quad$ Participatory Developmental Programme

SIDA: Swedish International Development Cooperation Agency

UNDP: United Nation Developmental Programme

UNESCO-UIA: U.I.A. WORK PROGRAMMEME 'EDUCATION'

RIBA: $\quad$ Royal Institute for British Architects

UNICEF: The United Nations Children's Fund works for children's rights,

survival, development and protection

USAID: $\quad$ U.S. Agency for International Development 
HEBA SAFEY ELDEEN est professeure associée au département d'architecture de I'université du Caire. Elle a obtenu un master (2000) puis un doctorat (2004) à la Faculty of Fine Arts, au Caire. Elle est également coordinatrice de programme au département d'architecture de la faculté des sciences de I'ingénieur de Misr International University (MIU), et professeure adjointe au département des arts de l'université américaine du Caire (AUC). Par ailleurs, elle est membre du programme " enfance et architecture » de l'union internationale des architectes, du comité architectural du conseil supérieur de la culture d'Egypte, du conseil d'administration de la société égyptienne pour la culture et le développement.

Elle a enseigné et conçu des cours sur le logement, I'urbanisme participatif, la planification et la conception urbaine, les méthodes de conception et de recherche, ainsi que la psychologie environnementale. Elle a publié plus de 15 articles dans des revues spécialisées en architecture. Parmi ses publications : Al'Kahira: Khawater 'omraneya (Cairo: Urban Thoughts) ISBN 977-179876-6, Al-Ta'3leem El-Me'mary: Al-Bedaya (Architectural Education: The Beginning) ISBN 977-17-9877-4.

HEBA SAFEY ELDEEN, Associate Professor of Architecture. Graduated (1993) and Attained Masters Degree (2000), and Ph. (2004) In the Faculty of Fine Arts, Cairo. Quality Assurance Coordinator \& Program Coordinator, Department of Architecture, Faculty of Engineering Science, Misr International University (MIU). Member, Union of International Architects (UIA): Program "Architecture and Children". Member Architecture Committee, Supreme Council of Culture, Egypt. Board Member, Egyptian Society for Culture and Development (formerly: Integrated Care Society) Adjunct Professor, Department of the Art, the American University in Cairo (AUC).

Taught and designed courses of Housing, Community and Participatory Design, City Planning and Urban Design, Design and Research Methods, Environmental-Behavioral Studies Organized. Published more than 15 Articles in local and international professional architectural and urban refereed journals. Publications: Al'Kahira: Khawater 'omraneya (Cairo: Urban Thoughts) ISBN 977-17- 9876-6, Al-Ta'3leem El-Me'mary: Al-Bedaya (Architectural Education: The Beginning) ISBN 977-17-9877-4. 


\section{REFERENCES}

AMnESTy, 2011, "We Are Not Dirt": Forced Evictions in Egypt's Informal Settlements. Amnesty International Cairo: Egypt.

Abdelhalim K., 2010, Participatory Upgrading of Informal Areas. A Decision Makers' Guide for Action. Participatory Development Programme in Urban Areas (DPD). Cairo, Egypt.

CAstells M., 1972, "Urban renewal and social conflict in Paris" In: Social Science Information Vol. 11, p. 93-124.

Castells M., 1977, The Urban Question. A Marxist Approach (Alan Sheridan, translator). London, Edward Arnold, 1977, (Original publication in French, 1972).

IBRAHIM M., 2009, Towards Reliable Spatial Database of Informal Areas in Greater Cairo Region: Identifying Informal Areas in Greater Cairo Region. International Workshop on Spatial Information for Sustainable Management of Urban Areas. FIG Commission 3 Workshop 2009. Mainz, Germany.

Piffero E., 2010, "Best Practices" in Practice: Critical Reflections on International Cooperation and Participatory Urban Development in Cairo Informal Areas, Egypt. Universitas Forum, Vol. 2, $\mathrm{n}^{\circ} 1$ September 2010.

Safey Eldeen H. \& Farahat B., 2011, Towards a Quality Assurance of the Private Architectural Education. Proceedings of ICERI 2012. International Conference of Education, Research \& Innovation. Madrid, Spain.

Safey Eldeen H., 2009, "Them and Us". Towards Incorporating the Concept of "the Other" Between Cairo Subcultures: An Educational Approach. Proceedings of $5^{\text {th }}$ International Conference: New Glasses: Presentation and Representation Department of Architecture. Faculty of Engineering - Cairo University, Cairo, Egypt.

- 2010. Discourse: A Hidden Curriculum In Undergraduate Architectural Education. Proceedings of the International Conference on Education and New Learning Technologies (EDULEARN10). Barcelona, Spain, 5-7 July 2010.

- 2012, National Developmental Agenda On Architecture Students' Learning Diaries: An Experiential Learning Approach. Proceedings of the INTED2010 (international Technology, Education and Development). Conference, Valencia, Spain.

- 2012, Participatory Design: Bridging the Gap between Education and Practice. Proceedings of: Design Build Studio: New Ways in Architectural Education. International Symposium for CrossCultural, Practice-Oriented Projects in Teaching and Research. Technical University of Berlin. Berlin, Germany.

- 2013, Towards Promoting Self-Help Initiatives in Cairo Informal Areas. Proceedings of REALCORP 2013 Planning Times. Rome, Italy. 
Sims D., Sejourne M., 2008, The Dynamics of Peri-Urban Areas around Greater Cairo: Concept Note. Egypt Urban Sector Update, World Bank ESW.

SheHAYEB D., 2009, Advantages of Living in Informal Areas. In: FISCHER, Marion \& KIPPER, Regina. 2009. Cairo's Informal Areas: Between Urban Challenges and Hidden Potentials. Cairo, Egypt.

World Bank, 2008. Arab Republic of Egypt: Urban Sector Update. Vol. 1. Sustainable Development Department, Middle East and North Africa Region. 